\title{
THE ESTIMATION OF GHG EMISSIONS FOR HOTELS IN ASIAN INSTITUTE OF TECHNOLOGY AND CHIANG MAI HILL 2000, THAILAND
}

\author{
Luansak Supansa
}

School of Environment Resources and Development, Asian Institute of Technology

Klong Luang, Pathumthani 12120, Thailand

*Corresponding author :sluansak@gmail.com

Received : 28 September 2015

Accepted : 27 November 2015

\begin{abstract}
In the tourism sector, hotel industry is one of the most important sub-sector. This hotel industry emits greenhouse gas $(\mathrm{GHG})$ emissions mainly carbon dioxide (CO2) by consuming large amount of energy, water, and non-renewable resources in service operation everyday on basis. This paper presents results of analysis how much does the GHG emissions release in hotel. The Asian Institute of Technology Conference Center and Chiang Mai Hill 2000, Chiang Mai, Thailand have successfully estimated GHG emissions by using Bilan Carbone ${ }^{\circledR}$ tool. The mitigation options are to encourage low carbon dioxide hotels. The data collection was done by questionnaires, interviews, and observations in both of them hotels. The results of annual GHG emissions contributor both Chiang Mai Hill 2000 as 3,844 t CO2 and at AITCC about 1,011 t CO2. Energy use is a major emission contributor followed by travel, property, input material, waste generated, and freight. Higher number of guests/tourists flow, effected higher used of facilities such as electricity, air conditioning, lighting, and food \& beverage. Larger size hotel service quality, greater guest room service, wide range of building area, greater facilities, and large functional are consumed higher energy and materials. As well as, the higher rate of room turning can also increase of emissions. Moreover, Chiang Mai Hill 2000 tends to take transportation which have longer distance than AITCC. Therefore, increasing higher journal distance generated higher GHG emissions as well. The short term and long term mitigation plans can also be taken into consideration to reduce $\mathrm{GHG}$ emissions. The recommendation of short term mitigation plans can be applied directly in both hotels thus, increasing awareness about climate change and energy conservation among uses. The long term mitigation plans recommends to give "Green Hotel" award to successful hotels for reducing GHG emissions in hotel. These plans can be incorporated the Thailand's government policy to reduce the impacts of climate change to the hotel industry.
\end{abstract}

Keywords: Climate Change Mitigation, Global Warming, Sustainable Tourism Development, Climate Change Policy, Bilan Carbone Tool, GHG emissions of Chiang Mai, Thailand.

\section{INTRODUCTION}

Climate change is one the most serious issues faced by society today. Anthropogenic activities (human-made) are important contributors of greenhouse gas (GHG) emissions in the recent decades, leading to global temperature rise. Tourism sector contributes to approximately $5 \%$ of these emission (UNWTO, 2009). Carbon dioxide (CO2) emissions by the global tourism scenario is expected to increase by 130 per cent in 2035. The varied impacts of climate change is evident around the world destinations and also effects tourism and travel industry, and the communities. Tourism is one of the largest global economic sectors that significantly contributes to many national and local economies around the world. There were 922 million international tourists with tourism receipts of US\$ 44 billion in 2008 (UNWTO, 2009). The global travel and tourism industry contributed 9.6 per cent to the global Gross Domestic Product (GDP) and is responsible for about 7.9 per cent of worldwide employment in 2008. The tourism industry of Thailand is one of the largest sectors, according to World Travel and Tourism Council's (WTTC), in 2007. Thailand tourism industry contributes a gross output income of 12.6 per cent of the country's gross domestic product (GDP). The gross output is expected to increase to 1.8 trillion Baht in 2017. The number of job creation was 1.9 million, which is the 5.3 per cent of the country's workforce. The number of employees is expected to increase from 4.11 million people to 4.76 
million people in 2017 (WTTC, 2007). The three major sub-sectors that contribute emissions of carbon dioxide for $93 \%$ are aviation (40\%) travel by car (32\%), and accommodation (21\%) (Scott, and Owens, 2010). The hotel industry is one important sub-sector of the tourism sector which produces greenhouse gas emissions (mainly CO2) by consuming large amount of energy, water, and non-renewable resources. Hotel is a tourism sub sector which consumes large amounts of energy. The hotels are to accommodate visitors, tourists, and excursionist, and have air-conditioning units, artificial lighting, and others that is in operation throughout the entire year. Increase in hotels equally increases the energy consumption. Renewable energy is a suitable option that can encourage to reduce energy consumption as well as GHG emissions reduction. There are many mitigation options for GHG emissions reduction which encourages sustainable tourism. This paper presents results of analysis on the estimation GHG emission at Asian Institute of Technology (AITCC) and a hotel selected is Chiang Mai Hill 2000. Bilan Carbone software tool was directly applied for estimation process in both hotels. To identify the major hotel activities that contribute to GHG emissions and has found the suitable GHG emissions reduction. The GHG emissions reduction results can also be reduced and thus encourage hotel industry design low Carbon Dioxide hotels.

\section{THE CONDITION OF RESEARCH LOCATION}

Chiang Mai is a large province and its ranks as second largest city in Thailand. The province is located away from Bangkok about $700 \mathrm{kms}$. The administration of the Chiang Mai municipality is approximately 40,216 square kilometers and consists of 70,000 households and is populated about 1.6 million people. The province is well-known for its natural beauty, unique culture and modern city life where contribute to tourism becoming an important economic sector. Chiang Mai tourism has fully service function which its categorized in 3 sub sectors are transportation, accommodation, and activities. The total number of visitors, tourists, and excursionist are following; 7,089,792, 5,590,080, and 1,499,721 (Chiang Mai Provincial Office of Tourism and Sport, 2013). The accommodation has been increasing in order to serve tourists during their stay. Table 1 presents the total number of accommodation in Chiang Mai province.

Table 1: Summary information of hotels in Chiang Mai District Area

\begin{tabular}{lll}
\hline Hotel (Group categorized by room service fee) & Total (hotels) & Total (Rooms) \\
\hline Hotel group1 (2,500 Baht) & 48 & 3,814 \\
Hotel group2 (1,500 - 2,499 Baht) & 42 & 2,887 \\
Hotel group3 (1,000 - 1,499 Baht) & 36 & 4,323 \\
Hotel group4 (500 - 999 Baht) & 96 & 7,108 \\
Hotel group5 (lower 500 Baht) & 66 & 3,176 \\
Guesthouse & 141 & 3,176 \\
Outside Municipality area and Resort included & 46 & 6,366 \\
Other & 46 & 1,731 \\
\hline Total & 662 & 32,650 \\
\hline
\end{tabular}

Source: (Complied from Statistic Division of TAT, 2013)

The large hotel seize is the most generate the GHG emission in tourism sector in Chiang Mai municipality. According to the study of AIT and Municipality of Chiang Mai results, summary of the GHG emission by tourism activities is from the large hotel seize. Figure 1.1 present the proportion of GHG emissions by tourism activities in Chiang Mai municipality. These activities release such a huge amount of GHG emission where Chiang Mai municipality has not been planning to reduce the emission yet. Therefore, the large hotels, restaurants and transportations are the most activities that contribute GHG emission in tourism sector. 


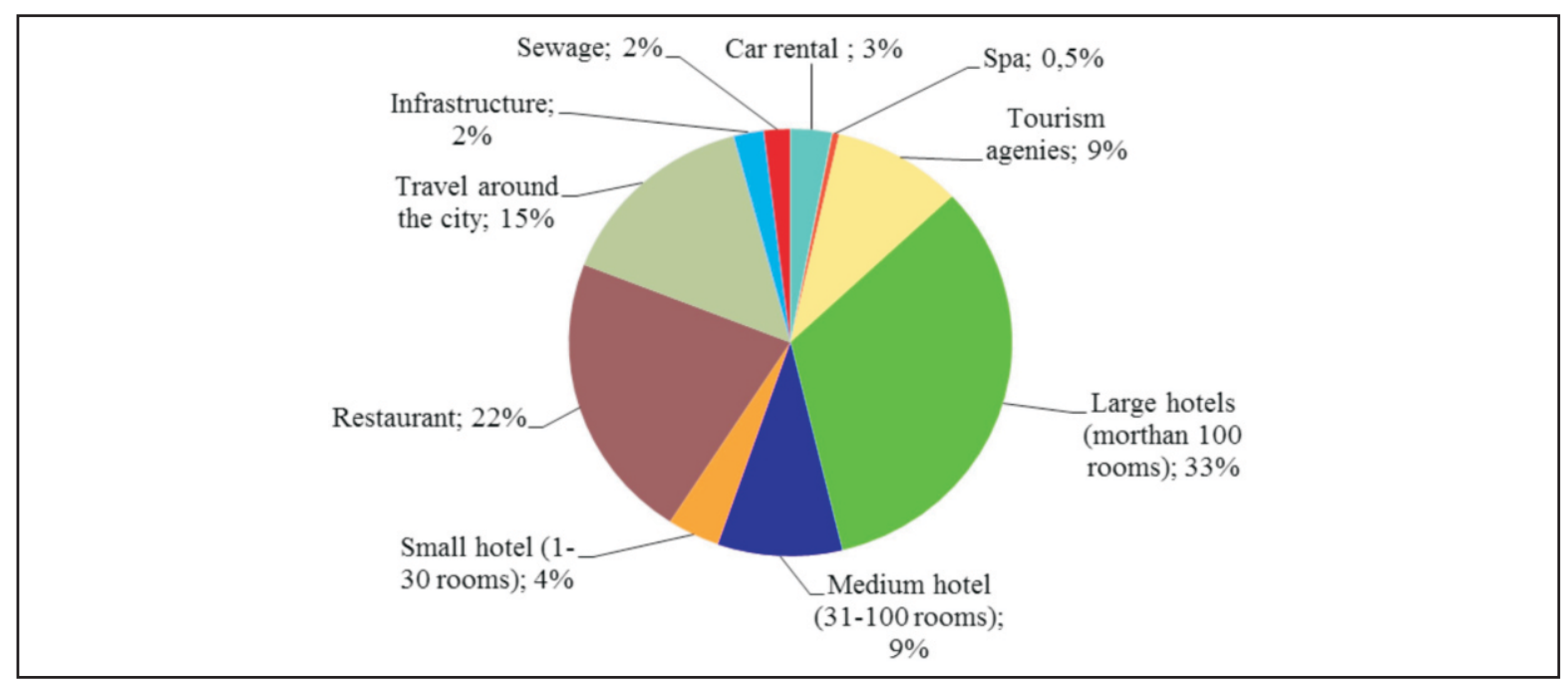

Figure 1. Proportion of GHG emissions by tourism activities. Source: (AIT, 2011)

\section{METHODOLOGY}

The Bilan Carbone spreadsheet can be used to calculate the greenhouse gas (GHG) emissions, which are generated by each activities producing goods or services in either public companies or authorities. Bilan Carbone is available in 3 different modules, namely, for

- Industrial or tertiary companies

- Local authorities with respect to jurisdictions and services related

- Territories

The methodology evaluates by scale, and the greenhouse gas emissions which result from physical processes due to human activities and organizations. There are 2 different fundamental points to indicate the physical processes from human and organizations,

- Greenhouse gas emissions emitted directly within the entity

- Greenhouse gas emissions emitted outside the entity

Tool Description and Data Sources

\section{Energy Use}

Energy use refers the emissions related to the energy produced by fixed source, namely,

- The use of combustion in fixed installations

- The use of fixed installations, for example electricity consumption in building.

\section{Excluding Energy Use}

Excluding energy use emits greenhouse gases beside coal, oil, and gas such as.

- Methane emissions are created by putrefaction and fermentation.

- Nitrous oxide emissions are created by spreading of nitrate fertilizers.

- Leak of cooling fluids were created by the use of cold chains.

\section{Input or incoming Material}

The input materials refer to raw materials, semi-finished products, and others which consists of raw materials, equipment, office supply, and others in following department and are classified in the hotel activities listed below:

- Room guest service

- Restaurant and Coffee Shop 
- Spa and Massage

- Meeting and Convention

- Front Desk and Front area Space

- Administrative Area

- Laundry

- Activities

- Maintenance

Future packaging refers to packaging of product sold.

The packaging of product sold are not disposed directly. The emissions related are with plastics, papers, metals, and others. According to hotels is service, there no product to be considered. Therefore, this activity is not considered in this study.

- The packaging is always generated as waste where is unknown future waste generated to.

- If manufacture change or reduce product quantity, influenced to decrease by this total.

Freight

Freight refers to the goods/materials internal transportation and external transportation. Freight in this study refers to hotel activity in order to transport incoming materials from supplier to hotel, employees travel, and visitors travel. The activities classified are listed below.

- Incoming material delivered to hotel

- Raw material delivered to hotel

- Office supply and others delivered to hotel

Travel

Travel refers to home-work travel, travel in working context, and visitors travel. The activities data are listed below.

- Employees travel data collected from travel inside - outside the administrative of Chiang Mai municipality area for working context and includes cover inside and outside Chiang Mai city (two way distance). The starting point is from home-work-home. The, AITCC data was collected considering employee home area to center.

- Visitors travel data was collected from international visitors who were assumed to travel by airplane from Bangkok - Chiang Mai - Bangkok Airport. The starting point from Chiang Mai airport-hotel-Airport and mode of transport and distance are included. The, international visitors data of AITCC was collected from Suvarnabhumi airport to AITCC.

- The domestic visitors travel was two way from Home - hotel - Home and places of visits are excluded.

\section{Direct waste}

Direct waste refers to recycling, biological treatment of fermentable waste, hazardous waste, nonhazardous waste and waste water of hotel. The activities data are classified as

- Non-Hazardous wastes

- Wet trash and dry trash

- Waste water

Property

Property of hotel refers to roads and car park, vehicles, machines and tools, and IT. The activities are.

- Computers, and office supply (printers, photocopiers and fax machines).

- Buildings, roadways, and car parks.

The spreadsheet estimates the property considering, buildings, road infrastructures (car parks included), machines and production lines, and vehicles. Table 4.7 presents the data requirement due to data collection. 


\section{HOTELS SELECTED FOR CASES STUDY}

The AITCC is located on the AIT campus in Klong Luang, Pathumthani province, Thailand. The centers provides facilities, accommodation, and services for faculties, students, alumni, staff, visiting lecturers, course participants, and other visitors. The facilities cover a wide range of conference, and seminar requirements of $10-500$ participants. The 100 guestrooms have 3 different category suites, superior, and standard rooms. Restaurant with selection of dining is available. The center operates 24 hours every day and has 42 employees. Another hotel selected is Chiang Mai Hill 2000, Chiang Mai, Thailand. The Chiang Mai Hill 2000 Hotel is located at Huaykaew Road, surrounded by Chiang Mai zoo, Chiang Mai university, Doi Pui National Park, and Doi Suthep National Park, in the municipality area of Chiang Mai province, Thailand. It is located 5 kilometers from Chiang Mai international airport. There are many facilities, shopping mall, and attraction places surround the hotel. More than 224 guest rooms service are available in 4 categories namely; Standard, Deluxe, Superior, and President. They also provide facilities to accommodate conferences or events for 50 to 400 persons in the grand ballroom and 4 other dedicated function rooms completely equipped with audio, visual, and lighting technologies. A wide range of selected international, Thai, and local Chiang Mai cuisine is also available for guests/visitors.

\section{GHG EMISSION INVENTORY}

The modification of spreadsheet involved with AITCC and Chiang Mai Hill 2000 hotel activities requirement considered and data requirement for GHG Emission inventory following parameters. The figure 2 presents the GHG emission inventory of hotels as well as definition are defined in step of estimation processes.

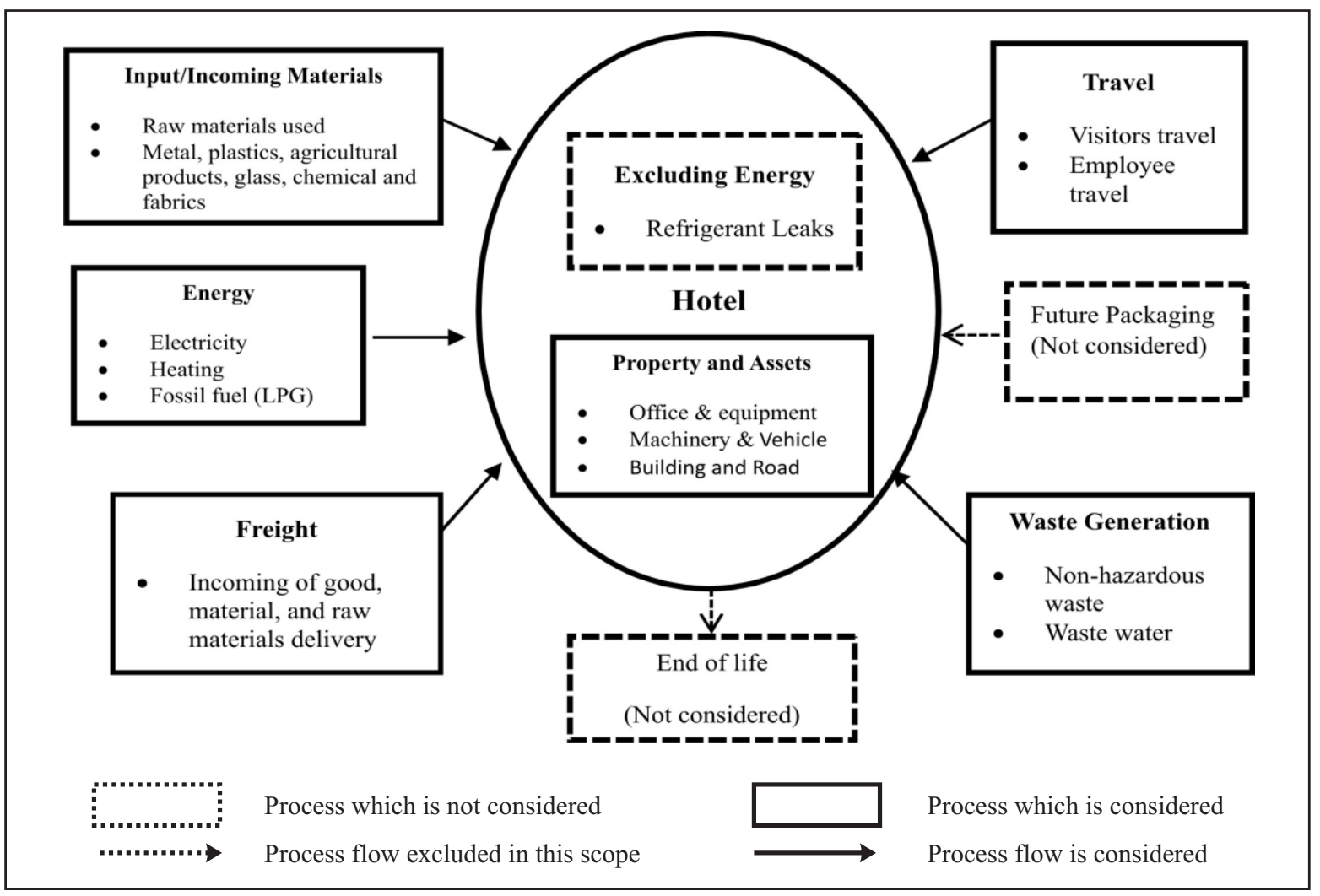

Figure 2. GHG emissions inventory of hotels 


\section{RESULTS OF ANALYSIS}

The total GHG emission as a result of the various activities of the hotel considered in this study is approximately 3,844 tones of $\mathrm{CO} 2$ eq. The highest GHG emission contributor is from energy accounting for 1,220 tones $\mathrm{CO} 2$ eq. This is followed by input material contributing 321 tones $\mathrm{CO} 2$ eq., freight 27 tones $\mathrm{CO} 2$ eq., travel 1,406 tones $\mathrm{CO} 2$ eq., direct waste 28 tones $\mathrm{CO} 2$ eq., and property 842 tones $\mathrm{CO} 2$ eq. The two major contributor of GHG emissions value are travel and energy. Figure 6.11 shows the annual emissions from various activities of the hotel.

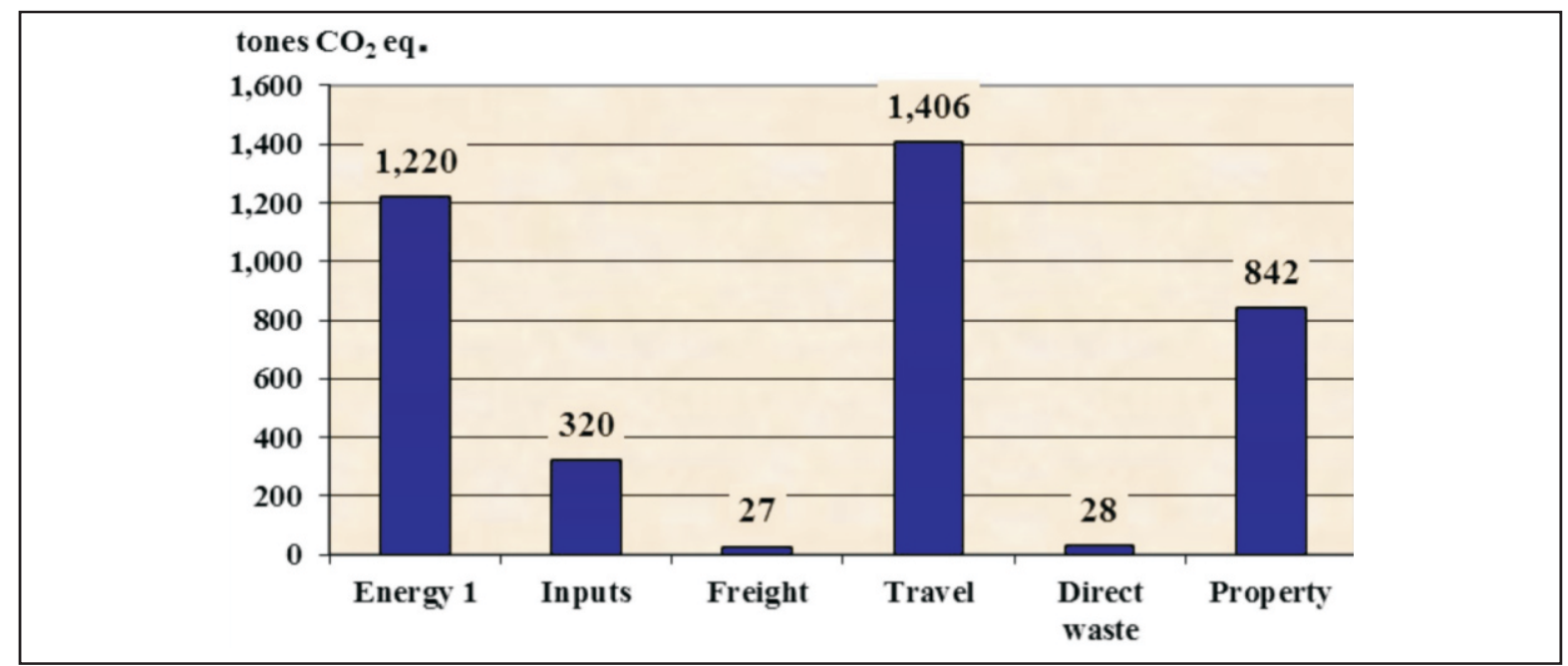

Figure 3. Summary of Annual GHG emissions by hotel activities considered of Chiang Mai Hill 2000, Chiang Mai, Thailand.

The total GHG emission as a result of the various activities of the hotel considered in this study are 1,011 tones $\mathrm{CO} 2$ eq. Energy is a majority of emissions contributor accounting for 707 tones $\mathrm{CO} 2 \mathrm{eq}$. followed by input materials by 132 tones $\mathrm{CO} 2$ eq., property by 131 tones $\mathrm{CO} 2$ eq., travel by 31 tones $\mathrm{CO} 2$ eq., freight by 5 tones $\mathrm{CO} 2$ eq., and direct waste by 5 tones $\mathrm{CO} 2$ eq. The figure 5.11 presents the summary of annual GHG emissions of various activities of the hotel.

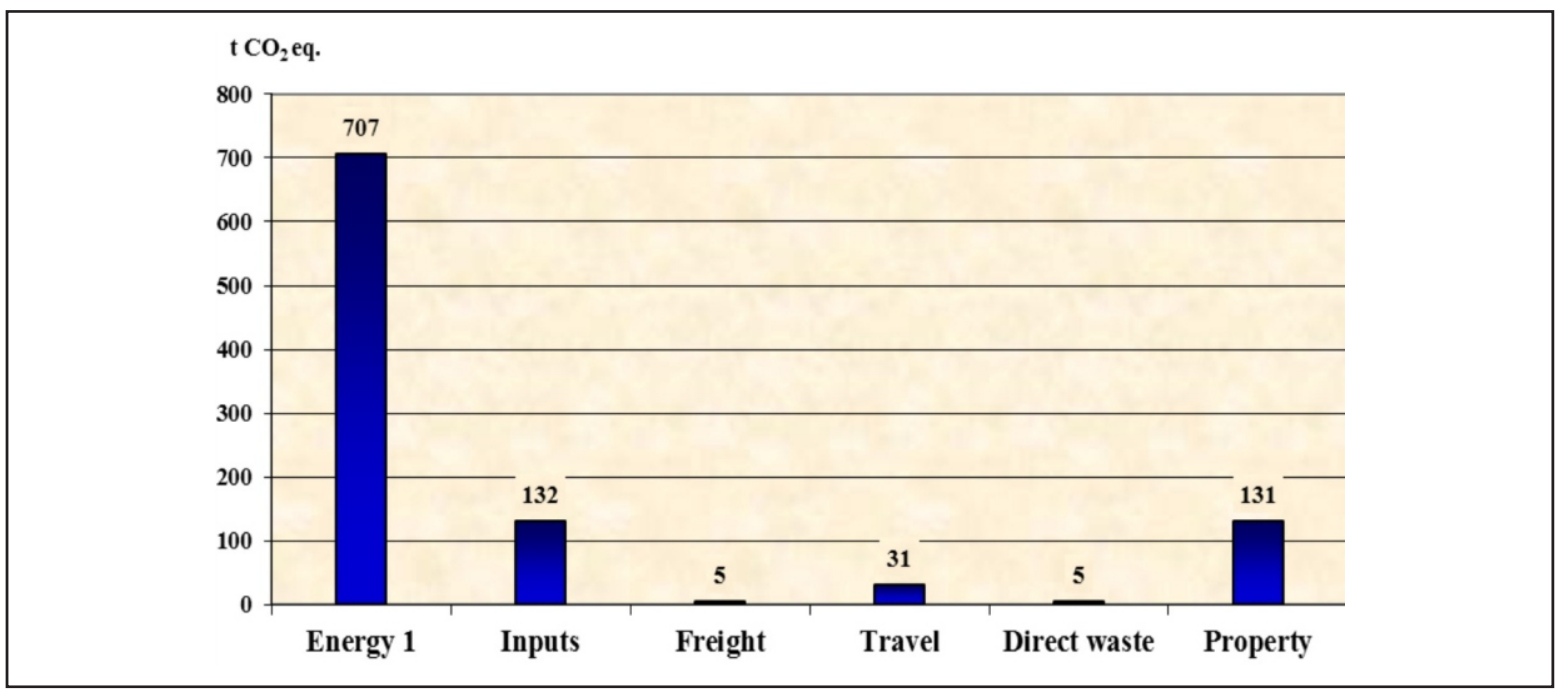

Figure 4. Summary of annual GHG emission of various activities at AITCC 
The differences results of analysis between AITCC and Chiang Mai Hill 2000 are:

1. The total annual GHG emissions value of Chiang Mai Hill 2000 has higher than AITCC. Because of number of guests/visitors flow are lower, effected to higher used of facilities such as electricity, air conditioning, lighting, and food \& beverage.

2. The Chiang Mai Hill 2000 has indicated more larger hotels sizes service quality to serve guests/visitors than AITCC. With greater guest room services, wide range of building area, greater facilities, and large functional are consumed higher energy and materials. The higher rate of room turning can also increase of emissions.

3. Among difference location of hotel, guests/visitors from Chiang Mai Hill 2000 tend to take transportation which increase higher distance than AITCC during a journey. The consumption of fossil fuels generated $\mathrm{CO} 2$ which contributor to environmental pollution.

Table 2: Summary of GHG emission according to various activities for sources of emissions.

\begin{tabular}{|c|c|c|c|c|c|c|}
\hline \multirow[t]{2}{*}{$\begin{array}{l}\text { Activities are } \\
\text { considered }\end{array}$} & \multirow[t]{2}{*}{ Source of GHG emissions } & \multirow{2}{*}{$\begin{array}{l}\text { AITCC } \\
\mathrm{t} \mathrm{CO}_{2} \text { eq. }\end{array}$} & \multirow{2}{*}{$\begin{array}{c}\text { AITCC } \\
\% \\
\end{array}$} & \multirow{2}{*}{$\begin{array}{c}\text { Chiang } \\
\text { Mai Hill } \\
2000 \\
\mathrm{t} \mathrm{CO}_{2} \text { eq. }\end{array}$} & \multirow{2}{*}{$\begin{array}{c}\text { Chiang } \\
\text { Mai Hill } \\
2000 \\
\%\end{array}$} & \multirow[t]{2}{*}{$\begin{array}{c}\text { Total } \\
\text { tones of } \\
\mathrm{CO}_{2} \text { eq. }\end{array}$} \\
\hline & & & & & & \\
\hline \multirow[t]{2}{*}{ Energy } & Electricity & 700 & 95 & 1,160 & 95 & 1,860 \\
\hline & LPG & 7 & 5 & 60 & 5 & 67 \\
\hline \multirow[t]{6}{*}{ Input } & Metal & 39 & 29 & 3 & 1 & 42 \\
\hline & Plastic & 21 & 16 & 82 & 25 & 103 \\
\hline & Glass & 2 & 2 & 12 & 4 & 14 \\
\hline & Paper \& Cardboard & 1 & 1 & 2 & 1 & 3 \\
\hline & Chemicals product & 3 & 2 & 16 & 5 & 19 \\
\hline & Agricultural product & 66 & 50 & 206 & 64 & 272 \\
\hline \multirow[t]{2}{*}{ Freight } & Outgoing road freight & None & None & 4 & 15 & 4 \\
\hline & Incoming road freight & 5 & 100 & 23 & 85 & 28 \\
\hline \multirow[t]{2}{*}{ Travel } & Home-work & 28 & 89 & 199 & 14 & 227 \\
\hline & Visitors all method & 3 & 11 & 1,207 & 86 & 1,210 \\
\hline \multirow{4}{*}{$\begin{array}{l}\text { Waste } \\
\text { generated }\end{array}$} & Non-hazardous waste & 0 & 3 & 1 & 2 & 1 \\
\hline & Waste recycled & 0 & 1 & None & None & - \\
\hline & Wet food waste & 3 & 53 & 27 & 98 & 30 \\
\hline & Sewage & 2 & 43 & None & None & 2 \\
\hline \multirow[t]{4}{*}{ Property } & Building & 126 & 96 & 826 & 98 & 952 \\
\hline & $\begin{array}{l}\text { Vehicle, machine, and } \\
\text { furniture }\end{array}$ & 1 & 1 & 11 & 1 & 12 \\
\hline & IT & 4 & 3 & 5 & 1 & 9 \\
\hline & Total & 1,011 & - & 3,844 & - & 4,855 \\
\hline
\end{tabular}




\section{REFERENCES}

ADEME, 2009. Bilan Carbone ${ }^{\circledR}$ : Companies-Local Authorities-Regions, Methodology Guide, Version 6, objectives and accounting principles, the French Agency for Environment and Energy Management(ADEME), France.

ADEME, 2010. Bilan Carbone ${ }^{\circledR}$ Carbone Emission Factor Guide, Version 6.1 emission Factor calculation and bibliographical sources used. the French Agency for Environment and Energy Management (ADEME), France.

AIT, 2012. Sustainable urban tourism through low carbon initiatives : Experiences from Hue and Chiang Mai an inventory of greenhouse gas emissions from tourism related activiteis in Chiang Mai Municipality, Thailand.

AIT, (2013). Action towards Resource-efficient and Low Carbon Cities in Asia., Thailand.

Alamoudi, R. H. (2008). Resource Use, Waste and Total Productivity Management in Saudi Arabia Hotel Industry, 43-54.

Barker, T., 2007. Climate Change 2007 : An Assessment of the Intergovernmental Panel on Climate Change, (November), 26-73.

Becken, S., Frampton, C., Simmons, D., 2001. Energy consumption patterns in the accommodation sector - the New Zealand case. Ecological Economics, 39(3), 371-386.

Becken, S., Simmons, D., 2002. Understanding energy consumption patterns of tourist attractions and activities in New Zealand. Tourism Management, 23 (2002), 343-354.

Carbone, B., 2010. Bilan Carbone ${ }^{\circledR}$ for an industrial or tertiary company Users ' manual for the spreadsheet, (June).

Chan, W., 2012. Energy benchmarking in support of low carbon hotels: Developments, challenges, and approaches in China, benchmarking in support of low. International Journal of Hospitality Management, 31(4), 1130-1142.

Chan, W. W., Li, D., Mak, B., Liu, L., 2013. Evaluating the application of solar energy for hot water provision: An action research of independent hotel. International Journal of Hospitality Management, 33, 76-84.

Cheung, M., \& Fan, J., 2013. Carbon reduction in a high-density city: A case study of Langham Place Hotel Mongkok Hong Kong. Renewable Energy, 50, 433-440.

Chiangmai Provincial Office of Tourism and Sports., 2012. Thailand Tourism Standard. Retrieved August from URL:http://www.cm-mots.com/

Kumar, S., Kusakabe, K., Pradhan, P., Shrestha, P., Goteti, S., Tuan, T. A., 2011. Greenhouse Gas Emissions from Tourism Service Providers : Case Studies in Chiang Mai, Thailand and Hue, Vietnam.

Littee Kitpipit., 2007. Energy Use in The Tourism Industry of Thailand. (Master thesis study No. ET-0723, Asian Institute of Technology, 2007). Bangkok: Asian Insitute of Technology.

Ministry of Tourism and Sports., 2012-2016, National Tourism Development Plan

Nikhil Kolsepatil, 2011. Estimation of Carbon Footprint for an Indian Diesel Engine Manufacturing Industry. (Master Thesis study No. ET-11-05, Asian Institute of Technology, 2011). Bangkok: Asian Institute of Technology.

Office of Natural Resources and Environmental Policy and Planing.,2011. Thailand's Second National Communication under the United Nations Framework Convention on Climate Change. Ministry of Natural Resources and Environment. Bangkok, Thailand. $102 \mathrm{p}$.

Simpson, M.C., Gossling, S., Scott, D., Hall, C.M., Gladin, E., 2008. Climate Change Adaptation and Mitigation in the Tourism Sector: Fameworks, Tools and Practices. UNEP, University of Oxford, UNWTO, WMO: Paris, France. 
Summit, E., Industry, T., Tourism, G., Tourism, E., \& Tourism, R., 2011. Thailand Tourism Standard 2011.

Tang, Z., Shi, C. B., \& Liu, Z., 2011. Sustainable Development of Tourism Industry in China under the Low-carbon Economy. Energy Procedia, 5, 1303-1307.

Tourism Authority of Thailand (TAT) Retrieved May 4, 2013, from URL: http://www.tourismthailand.org

TAT (Tourism Authority of Thailand)., Tourism Investment. Retrieved May 3, 2013, from URL:http://www.tourisminvest.tat.or.th/index.php

Thailand Greenhouse Gas Management Organization (Public Organization), Emission Factor. Retrieved March 5, 2014 from URL: http://thaicarbonlabel.tgo.or.th/download/ Emission_Factor_CFP.pdf

United Nations Environment Programe., 2010. Climate Change and Tourism Policy. Organisation for Economic Co- operation and Development/United Nations Environment programme.

United States Environmental Protection Agency., Global Greenhouse Gas Emissions Data. Retrieved November 2012 from URL:http://www.epa.gov/climatechange/ghgemissions/global.

UNEP, 2008. Climate Change Adaptatin and Mitigation in the Tourism Sector: Frameworks, Tools and Practices. University of Oxford, UNWTO, WTO: Paris, France.

UNWTO Background Paper, 2009. From Davos to Copenhagen and Beyond : Advancing Tourism ' s Response to Climate Change. Madrid, Spain 